University of South Florida

DIGITAL COMMONS

Digital Commons @ University of

@ UNIVERSITY OF SOUTH FLORIDA

South Florida

USF St. Petersburg campus Faculty

Publications

USF Faculty Publications

2014

\title{
Teaching Data Use and School Leadership
}

Charles Vanover

vanover@usf.edu

Olivia Hodges

Follow this and additional works at: https://digitalcommons.usf.edu/fac_publications

Part of the Scholarship of Teaching and Learning Commons

\section{Recommended Citation}

Vanover, C. \& Hodges, O. (2014). Teaching data use and school leadership, School Leadership \& Management: Formerly School Organisation, DOI: 10.1080/13632434.2014.962498

This Article is brought to you for free and open access by the USF Faculty Publications at Digital Commons @ University of South Florida. It has been accepted for inclusion in USF St. Petersburg campus Faculty Publications by an authorized administrator of Digital Commons @ University of South Florida. For more information, please contact digitalcommons@usf.edu. 
This article was downloaded by: [University of South Florida]

On: 07 November 2014, At: 10:09

Publisher: Routledge

Informa Ltd Registered in England and Wales Registered Number: 1072954 Registered

office: Mortimer House, 37-41 Mortimer Street, London W1T 3J H, UK

SLILC)

IEADEASHIPR

MANMiFMiEI

\section{School Leadership \& Management: Formerly School Organisation}

Publication details, including instructions for authors and subscription information:

http:// www. tandfonline.com/ loi/ cslm20

\section{Teaching data use and school leadership}

\author{
Charles Vanover $^{\mathrm{a}} \&$ Olivia Hodges ${ }^{\mathrm{a}}$ \\ a Department of Educational Leadership Development, University \\ of South Florida Saint Petersburg, Saint Petersburg, FL, USA \\ Published online: 23 Oct 2014.
}

To cite this article: Charles Vanover \& Olivia Hodges (2014): Teaching data use and school leadership, School Leadership \& Management: Formerly School Organisation, DOI: $10.1080 / 13632434.2014 .962498$

To link to this article: http:// dx. doi.org/ 10.1080/13632434.2014.962498

\section{PLEASE SCROLL DOWN FOR ARTICLE}

Taylor \& Francis makes every effort to ensure the accuracy of all the information (the "Content") contained in the publications on our platform. However, Taylor \& Francis, our agents, and our licensors make no representations or warranties whatsoever as to the accuracy, completeness, or suitability for any purpose of the Content. Any opinions and views expressed in this publication are the opinions and views of the authors, and are not the views of or endorsed by Taylor \& Francis. The accuracy of the Content should not be relied upon and should be independently verified with primary sources of information. Taylor and Francis shall not be liable for any losses, actions, claims, proceedings, demands, costs, expenses, damages, and other liabilities whatsoever or howsoever caused arising directly or indirectly in connection with, in relation to or arising out of the use of the Content.

This article may be used for research, teaching, and private study purposes. Any substantial or systematic reproduction, redistribution, reselling, loan, sub-licensing, systematic supply, or distribution in any form to anyone is expressly forbidden. Terms \& Conditions of access and use can be found at http://www.tandfonline.com/page/termsand-conditions 


\title{
Teaching data use and school leadership
}

\author{
Charles Vanover* and Olivia Hodges \\ Department of Educational Leadership Development, University of South Florida Saint Petersburg, \\ Saint Petersburg, FL, USA
}

\begin{abstract}
This case study uses evidence collected for accreditation and programme improvement at a small university Master's and certification programme in Educational Leadership Development to describe efforts to help leadership candidates use data during the programme's final internship experience. Programme features supporting the growth of candidates' instructional leadership skills are discussed as are the challenges faculty encountered supporting leadership candidates' efforts to use data to lead change projects. Suggestions for evaluating programmes' ability to teach evidence-based leadership practice are offered at the paper's conclusion.
\end{abstract}

Keywords: school leadership preparation; data use in schools; school improvement; school leadership internship experiences

\section{Learning to teach data use and school leadership}

This case study (Browne-Ferrigno 2003; Eisenhardt and Graebner 2007; Miles, Huberman, and Saldaña 2013) uses internal evaluation data from our university's Master's and certification programme in Educational Leadership Development Studies to explore a core question in the field of educational administration: What programme of study might best foster the development of teachers and other educational professionals into school leaders and support leadership candidates' efforts to use data to lead school improvement? Because this topic is so broad, we narrow our scope to discuss our programme's efforts to develop capacity to support candidates' abilities to use achievement and accountability data in their final internship experience in the practicum. We ask three related questions:

(1) What were the challenges of supporting candidates' efforts to learn to use data to lead instruction in the practicum?

(2) What programme features were found to best support candidates' growth in evidence-based leadership practice?

(3) How did candidates' learning and skills change over time?

In the conclusion, we discuss the implications of our case study for programme improvement and assessment in educational leadership preparation.

A case study on data use in a leadership preparation programme is significant because the ability to use assessments and other forms of data to set objectives and lead the change effort is a critical competency for school leaders (Boudett, City, and Murnane 2005; Louis et al. 2010). As Elmore (2004) argues, school improvement is an iterative, long-term process. To advance teaching and learning, leaders must use achievement data

*Corresponding author. Email: vanover@mail.usf.edu 
and other forms of evidence to understand the strengths and weaknesses of the teachers and students they serve and then do the right things to build on their school's capacity to solve challenges identified by the data (Coburn and Turner 2011; Spillane and Miele 2007). The extensive use and misuse of data in schools make improving curricula and field experiences that support candidates' efforts to learn evidence-based leadership an important goal (Hamilton et al. 2008; Paredes Scribner 1999; Skrla, McKenzie, and Scheurich 2009). Learning to engage in such work is difficult, as O'Day (2002) argues, because schools are flooded with information with little relevance to teaching and learning. Collecting useful data on student and adult performance and creating meaningful inferences 'requires time, resources, and knowledge that school personnel may not possess' (300). Without the knowledge of how to use data skilfully, leaders may misalign their goals to the needs and capacity of the students and adults in their building and misinterpret core findings or focus on evidence not relevant to long-term improvement. Data must be used to support the growth of all students, rather than, as has been found in a variety of qualitative and quantitative studies of modal schools, used to focus on select groups of students while ignoring the needs of others (Gillborn and Youdell 2000; Neal and Schanzenbach 2010; Reback 2008).

In the paper's conclusion, we use the findings from our analysis to present a set of questions that may be used to guide programme improvement in data use in educational leadership preparation. We hope these questions will draw attention to this issue and stimulate productive scholarship that might build on the descriptive work in this case study.

\section{Literature review}

\section{The landscape of educational leadership preparation}

In the USA, university-based school leadership programmes are major vehicles for the delivery of courses and field experiences that lead to certification in school leadership and major targets of reforms intended to improve leadership candidates' knowledge and skills (Baker, Orr, and Young 2007; Bottoms and O’Neil 2001; Murphy 2005; Young, Peterson, and Short 2002). These programmes are intended to direct and support the transitions of classroom teachers and other educational professionals into leadership roles and support the development of skills and habits of mind beyond those that leadership candidates might pick up in their day-to-day job experience (Browne-Ferrigno and Muth 2004; Karanxha and Agosto 2012; Nevarez and Wood 2007; Orr and Orphanos 2011).

Before current efforts to reform leadership preparation in the USA began in the 1990s, McCarthy (1999) found that many university-based programmes offered an incoherent and, frequently, irrelevant group of courses that did little to foster the knowledge, skills and dispositions that would allow leadership candidates to step into their role and work to improve outcomes for all students. Hess and Kelley's (2007) analysis of university leadership preparation programme syllabi collected in 2004 and 2005 showed that many programmes did not provide a rich curriculum to support candidates efforts to lead improvement in schools and allow candidates to understand, in the words of Tucker and Codding (2002):

the crucial role of data in the drive for results, from the careful setting of targets to the collection, display, and analysis of implementation and outcome data to the use of data for 
setting goals, monitoring progress, allocating and reallocating resources, and managing the school program. (37, cited in Hess and Kelly $(2007,4)$ )

Hess and Kelley's (2007) analysis of university leadership preparation programme syllabi collected in 2004 and 2005, for instance, showed that only about $15 \%$ of the weeks in the syllabi they coded addressed the leadership demands of managing for results, and only $2 \%$ of coded course weeks focused on managing assessments in state accountability systems.

These and other criticisms have inspired the US and international reform movement committed to developing programmes of study in school leadership preparation that organise candidate experiences around instructional leadership and other sets of skills and habits of mind intended to support candidates' efforts to become successful change agents (Darling-Hammond et al. 2009; Martorell et al. 2010; Murphy et al. 2007). These reforms are founded around two critical assumptions: first, the practices of excellent school leaders may be analysed and taught (Leithwood et al. 1996); second, high-quality learning experiences in preparation programmes will lead to successful leadership practice among graduates. Orr and Orphanos (2011) collected surveys from 65 principals who graduated from what the researchers described as exemplary leadership programmes and surveys collected from a national sample of 111 principals who graduated from more typical programmes. Based on this comparison, Orr and Orphanos claim 'Quality preparation matters and contributes significantly to what graduates learn and, ultimately, to how they practice leadership and work to improve their schools' (50).

\section{Evidence-based leadership practice in schools and other educational organisations}

Previous research has shown that effective school data use requires a deep knowledge of communities, schools, assessment and instruction, as well as social and ethical goals for students and school staff members (Author 2009; Hamilton et al. 2008; Skrla, McKenzie, and Scheurich 2009). Without a commitment to ensure beneficial outcomes for all students, data from high stakes assessments may be used to deny students opportunities to learn and justify incoherent, school-level change efforts that do not build long-term capacity for improved student development (Booher-Jennings 2005; Firestone et al. 2002; Valenzuela 2004). When employed to beneficial ends, we view evidence-based leadership practice as an individual and school-wide process that requires leaders, first, to notice patterns within the data and apply the knowledge necessary to interpret their meaning (Coburn and Turner 2011) and, second, to use that evidence to guide a change process that creates measurable improvements in what teachers teach and students learn. If data are to be used as a resource for positive improvement, teachers and administrators should possess the assessment literacy necessary to make appropriate inferences from data (Stein and Nelson 2003; Supovich 2012). They should also work within an organisational setting where that evidence is shared publicly with stakeholders (Elmore 2004; Hamilton et al. 2008). The technology deployed to analyse and disseminate data from assessments, the school climate for collaboration between professionals and the time available for inquiry all may influence how data are used (Marsh 2012). Leadership can make a difference in the data use process by designing the routines and other collaborative structures that allow the school community to access and interpret local data and by motivating organisation members to build on the strengths of staff, students and community members and seek to close gaps between current student learning outcomes 
and those specified by local and national standards (Heritage 2010; Spillane 2012; Supovitz and Klein 2003).

Leading beneficial improvement efforts based on evidence might be viewed as organised around a cycle of three major stages. The first stage is the data use process described by Coburn and Turner (2011) which results in a set of implications about how the organisation functions and/or a set of problems that might be solved. Knowing what is wrong is not the same as changing it. Understanding a problem, and discussing its possible causes does not mean that leaders, teachers and students will alter the practices, actions and attitudes that contribute to that dilemma. As a result, the second stage is a collaborative action planning process that produces a written plan that provides the coordination necessary to promote organisational change (Boudett, City, and Murnane 2005; Firestone and Corbett 1988). Doing the work required to make sure this plan has been understood and, hopefully, accepted by school staff is the third stage of the process, as is providing the leadership necessary to help teachers and students do the daily work required to do things differently than they did before the plan was put in operation (Wiggins and McTighe 2007).

Positive change is both managed and led. In order for members of the school community to change their behaviours, members need a clear idea of the changes they are going to make and access to the tools necessary to accomplish their goals (Rowan and Miller 2007). Members should also be inspired, influenced and motivated to engage in the work (Leithwood and Duke 1999). Once the change process is underway, data must be collected and analysed to guide and evaluate progress and to allow members to reflect on their efforts (McLaughlin and Mitra 2002).

This article will discuss efforts to teach leadership candidates to use data for understanding school problems and for creating, leading and evaluating change efforts intended to improve school performance and student outcomes. We differentiate data from 'mere information' by the level of formalisation that shapes its use. Information becomes data when candidates have a clear plan to collect, analyse and use these findings to guide and evaluate their efforts to achieve school improvement goals.

\section{Methods}

The evidence discussed in this article was collected as part of the process of continuous improvement in an accredited Master's and certification programme in Educational Leadership located in a small university (SU) in a large urban district in a large state in the USA. Because the practices and routines used to collect and analyse these data are historically situated (Leavitt and March 1988; Wenger 1998), it is important to describe how the practice of data use at SU evolved.

SU was originally a branch of a larger university and then became a separately accredited university over a transition period that began around 2005. Originally, the SU leadership programme was governed by this larger university's department of educational leadership. In order to operate as a separate programme, SU and its department of leadership development applied for accreditation and then, subsequently, affirmation of this status from three accreditation bodies: SU's state department of education; the Southern Association of Colleges and Schools (SACS) and the National Council for Accreditation of Teacher Education (NCATE). State and national standards for educational leadership development in the USA at this time were constructed in response to a reform movement that sought to make the curriculum of university-based educational leadership programmes more field intensive and more relevant to schools (Bottoms and 
O’Neil 2001; Murphy 2005), and programme development and evaluation efforts at SU reflected this focus. Thus, the state department of education required SU to demonstrate that leadership candidates' field experiences were integrated into SU's courses, and that candidates were able to receive feedback on their efforts from both faculty and district personnel. NCATE required SU to design and evaluate courses where:

Candidates demonstrate the ability to use data-based research strategies and strategic planning processes that focus on student learning to inform the development of a vision, drawing on relevant information sources such as student assessment results, student and family demographic data, and an analysis of community needs. (National Policy Board for Educational Administration 2002, 2)

Candidates' ability to use data to lead improvement was thus a major focus of concern at SU from the time of the programme's founding.

The work required to apply for accreditation and reaffirmation; to manage and teach within programme policies and structures set up to promote high-quality student learning; and to report to internal and external stakeholders, such as the districts SU served, was organised into an open-ended internal evaluation that guided programme improvement. SU leadership faculty reported to a College of Education assessment committee and to a joint College of Education and district advisory board. These bodies set goals and targets for the leadership programmes' performance. The primary sources of data SU faculty consulted in this process were portfolios of leadership candidates' work. These portfolios contained critical course assignments that demonstrated candidates' understanding of the principles of school leadership and candidates' ability to apply these principles in the field. Evaluations of candidates' performance in their culminating internship in the practicum by SU's practicum supervisor and candidates' district mentors were also shared with internal stakeholders. During the years discussed in this article, 2007-2011, data systems were not set up for SU faculty to track more quantitative data about programme outcomes, such as placement rates and measures of candidates' effectiveness in their positions.

The case study data shared in this article were taken from records generated by this internal evaluation. These records were first reanalysed by programme faculty in Summer and Fall 2012, when the state began the process of changing its standards for school leadership. The previous set of state standards had emphasised instructional leadership, but this focus became more pronounced in the revised standards: the ability to use assessment and other forms of data to lead continuous improvement of a school's academic programme became the primary focus of leadership development and assessment in the state. In order to revise SU's leadership programme to meet these new standards, both authors engaged in self-studies (Cochran-Smith and Lytle 2009) of their work as teachers of school improvement and other related aspects of educational leadership. In order to study change over time (Miles, Huberman, and Saldaña 2013; Saldaña 2003), timelines were created to chart critical issues in teaching evidence-based leadership practice. These data display describe a variety of issues impacting teaching and learning both within and outside the courses and field experiences the authors directed. Finally, the first author and a former student evaluated a set of 15 practicum portfolios made by candidates during the time period of the evaluation. These sources of data are listed in Table 1 in the Appendix. 
We chose to publish an extended portrait (Lawrence-Lightfoot and Davis 1997) of the SU practicum supervisor's work teaching evidence-based leadership in the practicum over the 4 years she directed the course because we believed it was the most telling case, and best communicated what we learned from this investigation. While there are many studies of what are held to be leading edge programmes in educational leadership preparation, there is less focus on the change efforts of faculty working in ordinary programmes outside of the halo of foundation support. Unlike some of the model programmes described in Darling-Hammond et al. (2009), for instance, SU does not have the resources to offer full-time paid internships to its leadership candidates; instead, as will be discussed, field experiences, including a culminating internship in the practicum, are structured into the programme's curriculum and are negotiated between candidates, their mentors (usually their principal) and programme faculty. In order to ensure our results' trustworthiness and their connection to the empirical reality of life within our educational leadership programme (Lincoln and Guba 1985), we have shared drafts of our paper with faculty within the college of education, members of our programme's advisory board and former students.

\section{Portrait: teaching data use within changing internal and external environments - the practicum at $\mathrm{SU}$ from 2007 to 2011 \\ Case setting}

SU is located in an urban district that serves more than 100,000 students. About $40 \%$ of these young persons are members of minority groups, primarily Black $(19 \%)$ and Hispanic (9\%), and about $50 \%$ of the district's students receive free and reduced lunch. SU's leadership programme is small, with only two or three full-time, programme faculty who direct the educational experiences of small cohorts of between 5 and 12 leadership candidates admitted in the Fall and Spring. Candidates are required to have a 3.0 grade point average and at least 2 years teaching experience, as well as a valid teaching certificate. They must have two references from supervisors in their schools. A total of 72 students graduated from the SU leadership programme during the case study period. Programme faculty tend to teach the same classes within the programme's 12 course sequence, which works out to about $50 \%$ of the courses candidates receive. PhD-prepared adjunct instructors teach the other classes, most of whom work as local principals or central office leaders, teach the programme's other classes.

\section{The practicum at $S U$}

The practicum is a field-based course educational leadership candidates usually take in the final semester of their Master's programme. The course, by state guidelines, must be taught by an instructor with high levels of school-based leadership experience. At SU, the course was organised around an internship with two major components intended to be completed under the mentorship of one of the candidate's supervisors, usually his or her principal. The first component was a set of activities intended to give candidates practical experience in engaging in particular leadership skills. The second was a culminating project that was intended to challenge the candidate to use data from their school to attempt to solve an important problem. Throughout the time period discussed in this article, practicum activities and projects were negotiated between SU candidates, their 
mentors and SU practicum faculty according to a set of guidelines SU developed in consultation with the district. Most internships took place inside candidates' schools.

Making a candidate's supervisor their mentor brings up complex issues of power, knowledge and authority (Browne-Ferrigno and Muth 2004). Mentors who have personality conflicts with candidates might not push them to engage in projects that stretch candidates' instructional leadership skills. Other mentors might lack the skill or motivation to provide useful feedback on candidates' work. As a result, the quality of the internship experience might vary between candidates in ways that do not reflect candidates' ability levels. However, the use of supervisors as mentors has a number of practical benefits that have made this practice a stable component of the SU practicum experience. In order for candidates to move beyond their current jobs and engage in leadership work to prepare them for a new role, candidates must be freed from some of their current, day-to-day, job responsibilities or have the support necessary to take on more responsibility in their current position. In order for candidates to take on authentic problems in their school and make a difference in teachers' teaching and students' learning, school leaders must authorise these activities and agree to support their implementation. Having a candidate's direct supervisor act as their mentor greatly simplifies this process.

\section{7-2008: raising the quality of the practicum experience while working within programme constraints}

A new supervisor, the second author, was appointed to lead the practicum at SU in January of 2007. This supervisor had worked as a principal for two decades and had received an Ed.D. in another state. During the first two semesters she taught the practicum, the supervisor followed the format of the original syllabus (Table 1), which had been designed by a previous SU faculty member.

Working within this design for learning was complex because many of the activities candidates engaged in during their internships were structured around what the new supervisor experienced as a disjointed set of activities. Leadership candidates, for instance, were asked to develop a master schedule, shadow their principal, and go out to the community and engage in some type of project. These activities did not connect into an integrated and aligned set of field experiences. Candidates tended to view these activities as course assignments, rather than as authentic work that contributed to the operation of their school. There was no final project in the original syllabus that acted as a capstone experience. Candidates worked with their principals on projects they began in the previous semester in another SU field-based course, but were not challenged to engage in a unique, culminating effort that pushed them to widen their repertoire of leadership skills. Coordination between the course where this project was developed and the practicum was weak, and there was no clear theoretical framework guiding their development and implementation. Candidates frequently arrived at the practicum with projects containing major design issues or projects that had not been approved by their mentors.

Data were used in some of these activities and projects, but there was no real accountability or connectivity. Candidates tended to check off the different activities in the practicum, including the final project, as fast as they could. There was so much going on during the final semester, it was difficult for candidates to focus on their leadership work or reflect on their actions.

Throughout the 2007-2008 school year, the practicum supervisor focused on one major change strategy. She worked to teach data analysis and alignment to her classes and 
Table 1. Original practicum syllabi.

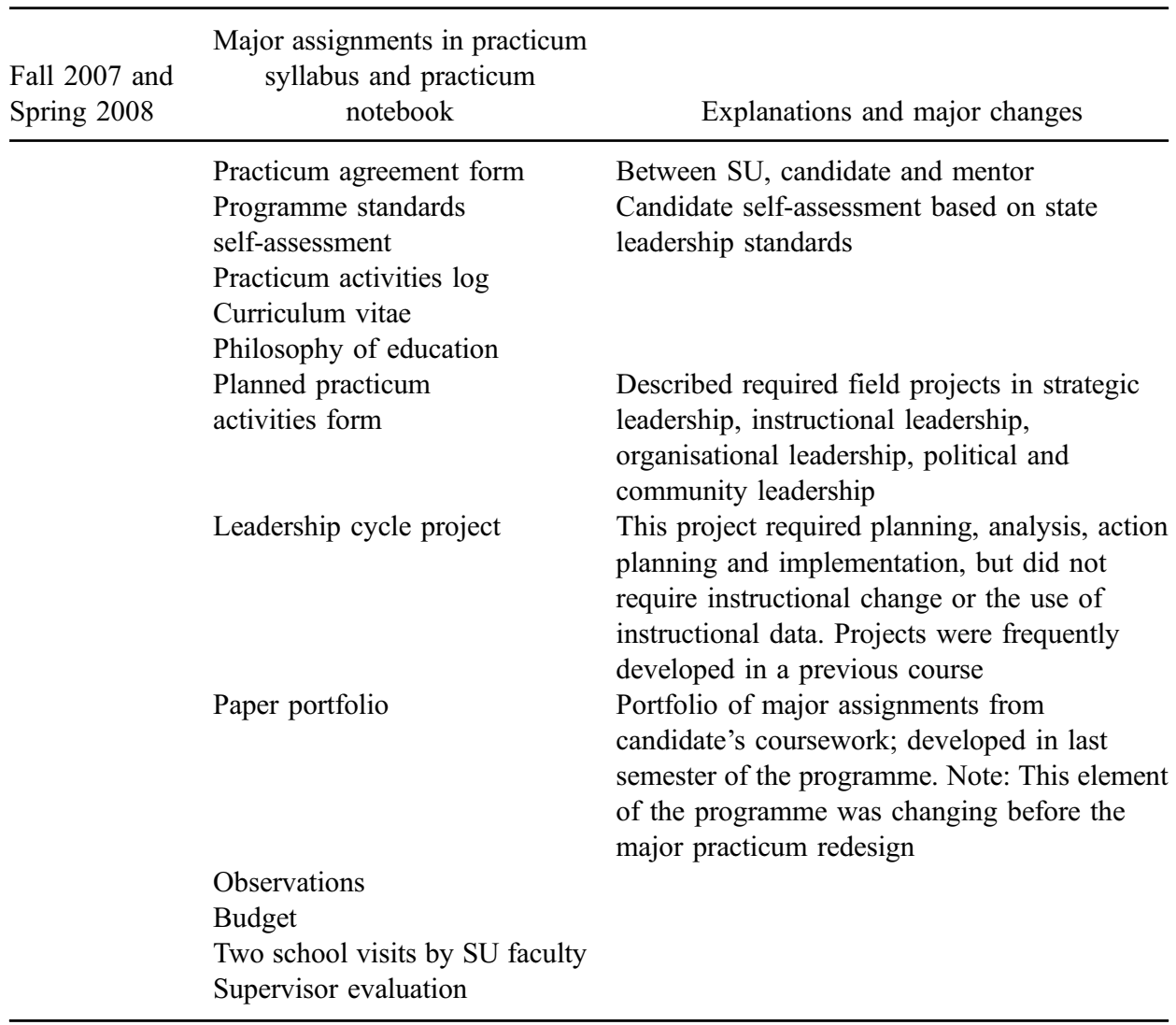

to develop relationships with the leadership candidates in her classes and with the principals and district leaders who, in theory, guided candidates' field experiences. She found that if she could develop a trust-based relationship with at least one other person in the mentoring triad (Bullough and Draper 2004; Gordon and Brobeck 2010), she could support higher quality practicum experiences, despite having no prior connection with candidates nor their principals. Candidates who trusted her had the motivation to work with her one-on-one and receive coaching on how to analyse data and link those findings to plans and actions. She could also help these candidates brainstorm and troubleshoot practical problems connected with particular projects and help them improve the quality of the work they completed in their schools. Mentors who trusted the practicum supervisor might decide to take more risks in guiding candidates' growth and give candidates more responsibility and authority.

The quality of the candidates' efforts varied. The weakest candidates were removed from the programme or required to purchase the credits to take the practicum a second time in order to improve their skills. Among candidates who passed the course, SU programme faculty differentiated the stronger from weaker candidates chiefly by their ability to use data to see problems and their motivation to solve them. The best graduates were able to identify core instructional issues, such as low comprehension skills, and lead 
the implementation of action plans to solve these problems. Strong graduates had the ability to both work independently and contribute as team members. Weaker candidates did not have the same ability to draw inferences from data and to lead improvement. They needed support from the school leadership team to act as effective leaders.

\section{8-2009: leading a redesigned practicum experience}

Over the spring and summer of 2008, the practicum supervisor redesigned the syllabus for the practicum (see Tables 2 and 3), working in tandem with another programme faculty member who worked as SU's leadership coordinator. This work was part of the SU leadership programme's overall effort to align its curriculum with state standards emphasising instructional leadership and achieve the goals SU put forward in its accreditation documents. One major change resulting from this redesign was to reduce the number of assignments in the practicum by moving important, but non-field based, assignments to earlier parts of the SU leadership preparation programme. Candidates now arrived at the practicum with their vitae and leadership philosophy already written. They were no longer asked to pull together and defend a portfolio of artefacts during the last semester; instead, this work was distributed throughout the programme as the candidates developed electronic portfolios. These changes were intended to create the time necessary for candidates to commit to projects they designed with their mentors. These changes were approved by SU's advisory board and the district's supervisor of leadership development and were formalised in a written document (Hodges, 2014). When there were questions about what type of projects might be appropriate and what type of support candidates might receive, practicum faculty might refer to these guidelines when they discussed the content of candidates' internships with mentors. Candidates and their mentors had a better idea of the work that was required because of these guidelines. Mentoring SU leadership candidates became a formal part of principals' and district leaders' work.

The course delivered in the Summer of 2008 included a major part of this revised curriculum. The practicum began with a 360 assessment where candidates, their peers, and the principals or district supervisors who acted as their mentors evaluated candidates' strengths and weaknesses. The 360 was developed by SU faculty according to a rubric based on SU's programme standards and aligned to state standards for school leadership.

Table 2. Changes to SU practicum.

\begin{tabular}{|c|c|c|}
\hline Summer 2008 & $\begin{array}{l}\text { Major assignments in } \\
\text { practicum syllabus and } \\
\text { practicum notebook }\end{array}$ & Explanations and critical changes \\
\hline & 360 assessment & $\begin{array}{l}\text { Replaced programme standards self- } \\
\text { assessment; candidates required to work } \\
\text { with their mentors and a peer to evaluate } \\
\text { their performance and create a programme } \\
\text { of self-improvement based on state } \\
\text { leadership standards }\end{array}$ \\
\hline & Leadership cycle project & $\begin{array}{l}\text { Revised; more use of achievement data; } \\
\text { stronger focus on school improvement plans }\end{array}$ \\
\hline
\end{tabular}


Table 3. Changes to SU practicum.

\begin{tabular}{|c|c|c|}
\hline $\begin{array}{l}\text { Fall } \\
2008\end{array}$ & $\begin{array}{l}\text { Major assignments in practicum } \\
\text { syllabus and practicum notebook }\end{array}$ & Explanations and critical changes \\
\hline & District university agreement form & $\begin{array}{l}\text { Added; spells out university and district } \\
\text { responsibilities }\end{array}$ \\
\hline & 360 assessment & Added summer 2008 \\
\hline & Curriculum vitae & $\begin{array}{l}\text { Revised; developed in an earlier course, the } \\
\text { principalship }\end{array}$ \\
\hline & Philosophy of education & $\begin{array}{l}\text { Revised; developed in an earlier course, the } \\
\text { principalship }\end{array}$ \\
\hline & Planned practicum activities form & $\begin{array}{l}\text { Revised; aligned to state educational leadership } \\
\text { standards; candidates required to complete a field } \\
\text { experience for each state standard. All candidates } \\
\text { required to complete an assignment aligned to } \\
\text { these standards before entering the practicum and } \\
\text { to write up focused annotation that describes why } \\
\text { that work meets state standards }\end{array}$ \\
\hline & Action research project & $\begin{array}{l}\text { Replaced leadership cycle project; candidates } \\
\text { required to use assessment data to analyse a } \\
\text { school problem and use data to assess their } \\
\text { efforts to lead a change effort. Candidates present } \\
\text { their work in a gallery walk for the university and } \\
\text { district community }\end{array}$ \\
\hline & Shadowing & $\begin{array}{l}\text { Added; candidates required to shadow their } \\
\text { mentor for a full day and report on her/his } \\
\text { activities }\end{array}$ \\
\hline & Observations & $\begin{array}{l}\text { Revised; field notes and analysis of interpersonal } \\
\text { dynamics in meetings between: A child and an } \\
\text { adult - usually special education or discipline } \\
\text { issues; Two or three adults - usually faculty } \\
\text { human resource issues }\end{array}$ \\
\hline & Budget & $\begin{array}{l}\text { Revised; aligned to district budgeting policies } \\
\text { and procedures }\end{array}$ \\
\hline & Digital portfolio & $\begin{array}{l}\text { Added; online portfolio of artefacts and } \\
\text { annotations aligned to state leadership standards. } \\
\text { Candidates start portfolios and receive feedback } \\
\text { before entering the practicum and are encouraged } \\
\text { to use practicum activities to complete portfolio }\end{array}$ \\
\hline & $\begin{array}{l}\text { Two school visits by SU practicum } \\
\text { supervisor }\end{array}$ & Continued \\
\hline & Supervisor evaluation of candidate & $\begin{array}{l}\text { Revised; aligned to district's administrative } \\
\text { appraisal process for assistant principals }\end{array}$ \\
\hline
\end{tabular}

Candidates, peer evaluators and mentors now began the SU practicum by using the 360 to list the candidate's strengths and areas of improvement. The candidate was then required to create an action plan to improve areas of weakness identified by the 360 and was approved by the other parties. This action plan helped guide the candidates' work in the practicum. Candidates were thus asked to begin the practicum by performing one of 
the foundational skills of evidence-based leadership practice: they were asked to use assessment data to set goals and targets for improvement.

In later years, initial data collection for the 360 was moved to a field-based course candidates completed immediately before the practicum, the principalship. This change allowed candidates and the practicum supervisor to analyse 360 data at the start of the practicum, without waiting to collect data from peers and mentors. At the end of the practicum, candidates were given a post-360 assessment: the original groups were given the same instrument and asked to evaluate the candidates' progress. To deepen the connection between candidates' work in the practicum and state standards for leadership preparation, in the Fall of 2008, the practicum supervisor aligned the course's Planned Practicum Activities Form to state standards for educational leadership. Mentors were asked to evaluate candidates' performance in the practicum using the same form principals used to evaluate assistant principals. SU records show, once it was put in place, all candidates completed the 360 assessment. The practicum supervisor and the candidates themselves, in their evaluations, found the assessment to be an important growth experience. The 360 required candidates to use data created by self, peer and supervisor evaluations to create a realistic change plan and to follow the plan's guidelines. Rather than checking through activities, motivated candidates were able to use the 360 to design internship experiences that helped them gain new knowledge and skills with an authentic connection to the work leaders performed in their district. Candidates whose mentors did not feel they had strong human resource skills might serve on the school hiring committee. Candidates who lacked experience working with parents and community members might create presentations for the School Advisory Council or, even, become chair.

By Fall semester of 2008, all the activities in the practicum syllabus were redesigned to align with state standards focused on instructional leadership and to provide practical experience in data use. These state standards required leaders to engage in databased decision-making, and the activities candidates engaged in to achieve these goals allowed programme faculty to ensure that candidates gained experience using evidence to make decisions. In order to support candidates' efforts to develop these skills in the field, candidates were asked to lead a capstone project that required them to create a baseline assessment of a major school achievement problem and lead improvement in that area. Most of these capstone projects were focused on grade-level or department-level achievement problems. Candidates might disaggregate district and state data about a particular issue, discuss these data collaboratively with faculty in their grade level or department, engage in research in this topic and then develop action plans to improve the identified area. Candidates would then discuss these activities with their mentors and with the practicum supervisor for initial approval. The plans would be developed further by other school leaders such as department heads and members of the school's leadership team. Candidates then implemented these projects and were required to evaluate the success of their work with data they collected and analysed. These findings were shared with school leaders and faculty and were written up as part of the capstone project. Some of these projects were quite ambitious. One candidate was assigned to work as the high stakes testing coordinator in her school and created an action plan intended to improve mathematics achievement school wide. Most projects had smaller scopes; some candidates used data to target a group of students and then managed during and after school tutoring programmes. Others worked to improve writing or science achievement in particular grade levels. These smaller projects 
usually aimed at specific student abilities, such as number sense and problem solving in mathematics or vocabulary development in reading.

All candidates presented their final capstone projects at a public gallery walk where their work was evaluated by school district personnel, faculty in the college of education and the chancellor of the university. These evaluations showed the quality of these final projects was uneven. One major area for improvement was candidates' use of technology: candidates tended to show low use of technology in their improvement plans and as a means to communicate with other teachers and community members. Depending on the cohort, candidates might also be low in instructional leadership skills or knowledge of strategic leadership. Candidates had particular difficulty discussing how they would lead and manage their projects once they got them underway and use formative data to respond to teachers' and students' needs. However, the work produced was sufficient to demonstrate candidates had mastered the content required by state standards and provided evidence the programme was achieving its goals. With varying levels of scaffolding, candidates were able to identify an area of their school's curriculum for improvement and lead an authentic change effort to improve the quality of students' school experience.

In subsequent years, this gallery walk became a major support for faculty's efforts to monitor the SU programme's quality.

\section{9-2011: building on strengths and filling in gaps}

Once the revised practicum experience was underway, SU faculty's focus changed from ensuring students completed a project, to ensuring that all projects were of high quality. One major issue faculty discussed as they evaluated candidates' projects was the difficulty in ensuring that the knowledge candidates gained from other courses and field experiences in the SU programme translated into usable knowledge (Author 2009; Spillane 2012) candidates might use during the practicum.

Many candidates entered the practicum with low levels of practical, assessment literacy. Topics related to this content were covered in the SU leadership programme's curriculum, and all candidates passed a state exam where they were tested on data use, but when candidates began to plan and enact data-based practicum projects, the practicum supervisor found candidates needed extensive support to create meaning from data available in their school and to plan an effective change project. Candidates had difficulty identifying a specific area for improvement within a particular subject. Weaker candidates had to be coached to move from talking about low math or reading scores to focusing on the specific student skills measured by the assessments, such as number sense or problem solving. Another area of difficulty was that, despite sometimes working in their schools for many years, many candidates had difficulties conceptualising an action plan that might improve teaching and learning in these areas. They did not know what to do to respond to problems identified by the data. Once the projects were under way, candidates had difficulties collecting and using formative data to monitor the improvement process and did not understand how best to use that evidence to adjust their efforts as the work began to unfold.

Candidates without a strong mentor were at a major disadvantage. Even if those candidates planned an ambitious change programme, it was challenging for them to lead that effort and manage the dilemmas involved in leading change in a buildings without a strong instructional leader. In some of these schools, the routines and collaborative structures (DuFour and Marzano 2011; Hamilton et al. 2008; Supovitz and Klein 2003) 
that supported data-based leadership were weak, and candidates had to work harder to do less. Receiving clearance to access administrator data systems, as opposed to the information available for teachers, might take a substantial amount of time. Scheduling teacher meetings where data connected to the change project was discussed might cause difficult logistical problems. In other schools, conflict between teachers and the administrative team created difficult dilemmas for candidates, mentors and the practicum supervisor.

One major programme response to these challenges was to push the skills candidates needed for evidence-based leadership practice earlier into the SU programme in order to give candidates both the time and the knowledge to lead beneficial change projects during the practicum (see Table 4). Faculty began to experiment with different ways to create authentic data-use experiences within the constraints of SU courses and to connect class projects with the needs of the district and schools. Candidates now began the SU

Table 4. Changes to SU practicum.

\begin{tabular}{|c|c|c|}
\hline Semester and year & $\begin{array}{l}\text { Major assignments in practicum } \\
\text { syllabus and practicum notebook }\end{array}$ & Explanations and major changes \\
\hline $\begin{array}{l}\text { Spring } 2009 \text { and } \\
\text { Summer } 2009\end{array}$ & $\begin{array}{l}\text { Minor changes to structure of } \\
\text { course }\end{array}$ & $\begin{array}{l}\text { Minor fine tuning of assignments; } \\
\text { fewer students who enter the } \\
\text { practicum from old portfolio system } \\
\text { walk into the course without initial } \\
\text { assignments completed }\end{array}$ \\
\hline Fall 2009-2011 & $\begin{array}{l}\text { Minor changes to structure of } \\
\text { course }\end{array}$ & $\begin{array}{l}\text { Developed a template for the format } \\
\text { of the action research project }\end{array}$ \\
\hline Spring 2009-fall 2011 & $\begin{array}{l}\text { On-going efforts to press data use, } \\
\text { action planning, and school } \\
\text { improvement skills earlier and } \\
\text { deeper into the SU curriculum. }\end{array}$ & $\begin{array}{l}\text { Added technology needs assessment } \\
\text { and implementation plan based on } \\
\text { action research principles to the first } \\
\text { course in the leadership programme, } \\
\text { Technology and Data; candidates } \\
\text { use state and district school } \\
\text { improvement plan data to describes } \\
\text { the problems confronting a local } \\
\text { high poverty school and an action } \\
\text { plan to begin the improvement } \\
\text { process in Curriculum } \\
\text { Improvement; candidates use state, } \\
\text { district and classroom data to study } \\
\text { the learning trajectories of two } \\
\text { students in their school in } \\
\text { Foundations of Curriculum. } \\
\text { Candidates use school improvement } \\
\text { plan data, as well as state and } \\
\text { district assessments, to evaluate one } \\
\text { area of their school's academic } \\
\text { programme in Programme } \\
\text { Evaluation; candidates collect but } \\
\text { do not analyse data for the } 360 \\
\text { evaluation in The Principalship }\end{array}$ \\
\hline
\end{tabular}


programme by evaluating their school's use of technology and creating an action plan to improve the use of these resources. At this time, the state published a database that contained rich information about individual schools, including the official school improvement plans. In their curriculum improvement class, candidates were asked to use these data to develop an action plan for a low performing school. As a result, during the later years in this time period, candidates began to enter the practicum with higher levels of assessment literacy. They had an easier time analysing school and district data, but they still needed direction on how to implement their action plans. It is also the case that the practicum supervisor became more skilful at managing both principals and leadership candidates and was able to provide more effective guidance to both parties. She learned how to coach principals to provide more focused support for candidates, and she learned to encourage them to trust candidates to lead important school projects. She learned how to coach candidates to ask for help from school leaders and their peers and to empower candidates to move beyond their grade levels and work on school-wide projects.

Despite these changes, guiding candidates' efforts to step up and act as leaders remained a complex task, and the quality of candidates' field experiences remained uneven. It was always a puzzle for the practicum supervisor to determine when to step in and teach candidates data use and leadership skills, and when it was best to empower them and let them do the work on their own. Candidates were not always able to take advantage of the independence the course offered and begin to make deep changes in their school. Throughout this time period, evidence from final practicum projects showed candidates engaged in more instructionally focused work, and began to complete more ambitious and academically focused change projects, but there was more to be done to ensure all candidates who entered the practicum, exited the course 'ready to go' with the skills and confidence necessary to step into an instructionally focused assistant principal role.

\section{Discussion}

In a sense, the case material we have presented supports one of the major points observed by Cohen and Moffitt (2009): the systems of feedback created by contemporary US educational organisations are not sufficient to support the development of practitioner expertise. SU and the districts it serves are located in a state with an historic commitment to accountability; however, for many of the teachers SU serves, this commitment had not reliably translated into the capacity (Coburn and Talbert 2006; Massell 2000) to use data skilfully and effectively for school improvement. Supporting local professionals' efforts to gain the skills and knowledge necessary to engage in this work became a major focus for SU faculty.

We found three programme features provided important supports for candidates' growth. The first was SU's 360 evaluation, which we found provided a metacognitive framework for candidates' work and, along with other curricular improvements, helped create a more meaningful field experience in the practicum. The 360 challenged candidates to plan a set of activities that would support their individual growth as leaders during the practicum. Collecting and analysing data to improve their own performance seemed to help candidates do a better and more thoughtful job as they engaged in other activities during the practicum. The second programme feature that supported programme improvement was SU's capstone project, which required candidates to use data to lead improvement in an important school problem. Planning and implementing this project became a major focal 
point of candidates' and their mentors' work, and helped focus the practicum on real-world skills. Instead of engaging in exercises that might or might not connect to real-world change issues, candidates became accountable for a recognised school problem. The gallery walk where SU leadership candidates presented their project also became an important site for assessment and reflection by programme faculty. Finally, SU's efforts to back-map (Elmore 2004) from the practicum and revise early courses to raise candidates assessment literacy before they engaged in the final internship experience allowed candidates to engage in deeper and more complex change projects. However, it is important to point out that evidence shows these supports did not operate reliably, and candidates continued to require scaffolding in data use and other forms of support to engage in evidence-based leadership.

During the time period covered by this article, candidates came to SU with different levels of knowledge of how to use data for school improvement, and while the programme could compensate for students who began the programme with gaps in their knowledge base, it was difficult to completely eliminate these differences. In schools with strong collaborative structures and routines for data use, faculty were empowered to own the data and to work as a team to create improvement projects. Candidates who worked in these schools were able to draw richer inferences from state and district data and had the confidence and support to lead projects that were focused on core student skills and were implemented without extensive resistance. We found that candidates with low assessment literacy frequently worked in schools that were not organised around evidence-based decision-making practices. In these schools, data might be analysed privately by the leadership team, rather than publically in a collaborative process. It was difficult to get ambitious projects off the ground when candidates did not have strong skills and their buildings lacked strong routines for improvement. While SU faculty could compensate for gaps in candidates' knowledge, candidates who entered the practicum with a strong foundational understanding of the what and the how of data use and leadership for change (Coburn and Turner 2011; Spillane 2012) had an advantage during their final internship experience. We found these candidates were able to do more, and, by doing more, learn more.

In our experience, a critical support for data use during the practicum was the web of relationships (Dutton 2003; Gordon and Brobeck 2010) that shaped candidates' experience as they worked on their change projects. Strong relationships between candidates and SU faculty that were organised more horizontally, around coaching and facilitation, rather than vertically, around traditional academic practices and authority relationships, were perceived to motivate candidates to work on areas of weakness and to take on ambitious, time intensive projects. Strong relationships between SU faculty and principals and other critical mentors that showed high levels of trust seemed to give mentors the confidence to ask more of their candidates and to push candidates to take on more responsibility. Many principals were not trained to use data when they took the courses for their leadership certification; trusting relationships with SU faculty gave these leaders the support and confidence necessary to guide candidates' development in ways the leaders, themselves, had not experienced. Weak relationships between members at one end of this triangle - such as candidates and SU faculty or mentors and candidates might be compensated by strong relationships at its other sides, but we found that it was rare candidates were able to complete ambitious change projects without deep connections either with practicum faculty or with their mentors. 


\section{Limitations and future research}

This case study is based on internal evaluation data. We organised data collected for accreditation and programme improvement into an exploratory investigation (Creswell 2009) that describes change over time in an important area of educational leadership preparation. It is important for other investigations to build on this effort and to explore candidates' learning during their final internship experience at other sites. Such inquiries might examine candidate learning trajectories (Orr, Young, and Rorrer 2010) in multiple leadership preparation programmes and investigate how different combinations of programme features and school and district level supports influence growth in candidates' evidence-based leadership skills over time.

We began this article by stating one of the core questions in the field of educational administration: What programme of study might best foster the development of teachers and other educational professionals into school leaders? Our investigation does not provide an answer to this question and does not make claims about the generalisability of particular reform strategies. Our inquiry does, however, allow us to reframe and distil this larger question into two driving questions with clear, actionable implications for programme improvement for SU and other leadership development programmes:

(1) Do leadership candidates have the knowledge and skills necessary to use evidence to identify a critical school problem, collaborate with school professionals to create an action plan, and step forward and lead improvement during their final practicum experience?

(2) If they do not, what knowledge do candidates need to learn and what field experiences do candidates need to complete to manage the demands of evidencebased instructional leadership?

We believe these driving questions represent an important contribution to the research on educational administration, because, as Goldring et al. (2009) emphasised, there are few instruments that assess K-12 school leaders' instructional leadership abilities. Along with assessments that evaluate leaders' practice by using multiple choice questions or written tests, our work might be used to develop performance assessments (Mislevy and Riconscente 2005) that focus evaluation on critical, real-world problems in educational leadership and ask candidates to use evidence for action planning and evaluation of projects of varying lengths. Rather than asking candidates to evaluate cases that occurred in other schools, candidates and other positional leaders, such as assistant principals, might be asked to use local data and collaborate with other professionals in their schools to solve specific school problems.

Such assessments might be used to examine leaders' knowledge of improvement in particular subjects, such as science or math, in various stages across the leadership pipeline and create university and district leadership preparation cultures focused on realworld change. Equity and community-based problems might also be assessed to ensure leaders gain the complex skills necessary to ensure beneficial outcomes for all students (e.g. Agosto et al. 2013; Brown 2004; Paredes Scribner 1999; Webb-Johnson 2006). Validating the rubrics and other materials used in such assessments might provide rich opportunities for research and theory building in educational administration. The developed instruments, themselves, might be used to support better policy, practice and learning. 
Our paper provides examples of the possible benefits of such efforts to intensify the field component of educational leadership development programmes. Our findings also strike a cautionary note about possible problems that might be created by such an approach to school leadership preparation. Contextual issues shape individual leaders' efforts to implement even highly specified reforms (Datnow and Castellano 2001; Rowan and Miller 2007), and educational leadership development programmes do not have the power to create thriving learning environments for students placed at risk in the schools their candidates serve, even if the creation of such environments might greatly enhance the likelihood of developing skilled, future leaders. The experience of working within modal schools and districts (Booher-Jennings 2005; Firestone et al. 2002; Spillane 2004) where data are not used collaboratively to empower teachers to engage in efforts to improve core academic skills may teach the wrong lessons to leadership candidates learning within these institutions. Dysfunctional schools and districts may create environments where strong candidates are unable to complete critical leadership tasks and weaker candidates are able to 'game the system' and complete their projects in ways that do not benefit the children they serve. Instead of developing leaders with a deep commitment to excellence and equity, intensifying candidates' field experience may reinforce systems of leadership behaviour that do not support real and lasting change. It is our opinion, however, that while these risks are real, no reform programme in educational leadership is possible if leaders cannot make meaning from their school's assessment data and use those findings to lead a beneficial change effort.

\section{Acknowledgements}

We would like to acknowledge Amanda Weinburg at the Pinellas County Schools and WilliamHeller and Rebecca Rhoden Ogletree at the University of South Florida Saint Petersburg for the feedback they gave us on an earlier version of this manuscript. We would like to acknowledge Serena Salloum at Ball State University; Tamara Young at North Carolina State University; Vonzell Agosto and Zorka Karanxha at the University of South Florida Tampa; and Gwen Webb-Johnson at Texas Agriculture \& Mines and for their participation in the UCEA symposium where this paper was developed.

\section{Notes on contributors}

Charles Vanover worked as a teacher-librarian in the Chicago Public Schools for 8 years. He received a $\mathrm{PhD}$ from the University of Michigan and worked as a case study researcher for the Study of Instructional Improvement and the longitudinal evaluation of the National Comprehensive Center for Teacher Quality (TQC). His research focuses on the ethnography of No Child Left Behind and other mass reforms and efforts to prepare school leaders to make a positive difference in the schools they lead and manage.

Olivia Hodges worked as a principal in three schools for 18 years in the Gwinnett County school district and received her Ed.D in Educational Leadership from Clark-Atlanta University in Atlanta, Georgia. During her last principalship, her school was recognised as a Georgia School of Excellence based on growth in student achievement over a 3-year period. She currently works as the programme coordinator of the University of South Florida Saint Petersburg Educational Leadership Development Studies programme and leads district and international accreditation reviews for AdvancED through the SACS. 


\section{References}

Agosto, V., L. Dias, N. Kaiza, P. McHatton, and D. Elam. 2013. "Culture-based Leadership and Preparation: A Qualitative Meta-synthesis of the Literature." In Handbook of Research on Educational Leadership for Equity and Diversity, edited by L. C. Tillman and J. J. Scheurich, 625-650. New York: Routledge.

Barnes, C., C. Vanover, \& J. Kim. 2009. "Evidence-based Leadership by Design.” Paper presented at the Symposium: Scaling Up and Sustaining Educational Improvement Programs in 38 schools in 6 Districts in 5 States." Accessed March 24, 2009. http://www.cpre.org/images/stories/ cpre_pdfs/aera2009_barnes_vanover_kim.pdf.

Baker, B. D., M. T. Orr, and M. D. Young. 2007. “Academic Drift, Institutional Production, and Professional Distribution of Graduate Degrees in Educational Leadership." Educational Administration Quarterly 43: 279-318. doi:10.1177/0013161X07303320.

Booher-Jennings, J. 2005. "Below the Bubble: 'Educational Triage' and the Texas Accountability System." American Educational Research Journal 42: 231-268. doi:10.3102/00028312042002231.

Bottoms, G., and K. O'Neil. 2001. "Preparing a New Breed of School Principals: It's Time for Action." Accessed June 18, 2012. http://www.wallacefoundation.org/knowledge-center/ school-leadership/principal-training/Documents/Preparing-a-New-Breed-of-School-Principals.pdf.

Boudett, K. P., E. A. City, and R. J. Murnane, eds. 2005. Data Wise: A Step-by-step Guide to Using Assessment Results to Improve Teaching and Learning. Cambridge, MA: Harvard Education Press.

Brown, K. M. 2004. "Leadership for Social Justice and Equity: Weaving a Transformative Framework and Pedagogy." Educational Administration Quarterly 40 (1): 77-108. doi:10.1177/0013161X0 3259147.

Browne-Ferrigno, T. 2003. "Becoming a Principal: Role Conception, Initial Socialization, Roleidentity Transformation, Purposeful Engagement." Educational Administration Quarterly 39: 468-503. doi:10.1177/0013161X03255561.

Browne-Ferrigno, T., and R. Muth. 2004. "Leadership Mentoring in Clinical Practice: Role Socialization, Professional Development, and Capacity Building." Educational Administration Quarterly 40: 468-494. doi:10.1177/0013161X04267113.

Bullough, R. V., and R. J. Draper. 2004. "Making Sense of a Failed Triad: Mentors, University Supervisors, and Positioning Theory." Journal of Teacher Education 55: 407-420. doi:10.1177/ 0022487104269804.

Coburn, C. E., \& J. E. Talbert. 2006. "Conceptions of Evidence Use in School Districts: Mapping the Terrain." American Journal of Education 112: 469-495. doi:10.1086/505056.

Coburn, C. E., \& E. O. Turner. 2011. "Research on Data Use: A Framework and Analysis." Measurement: Interdisciplinary Research and Perspectives 9 (4): 173-206. doi:10.1080/1536636 7.2011.626729.

Cochran-Smith, M., and S. L. Lytle, eds. 2009. Inquiry as Stance: Practitioner Research for the Next Generation. New York: Teachers College Press.

Cohen, D. K., and S. L. Moffitt. 2009. The Ordeal of Equality: Did Federal Regulation Fix the Schools? Cambridge, MA: Harvard University Press.

Creswell, J. W. 2009. Research Design: Qualitative, Quantitative, and Mixed Methods Approaches. 3rd ed. Thousand Oaks, CA: Sage Publications.

Darling-Hammond, L., D. Meyerson, M. M. La Pointe, and M. T Orr. 2009. Preparing Principals for a Changing World. San Francisco, CA: Jossey-Bass. doi:10.1002/9781118269329.

Datnow, A., and M. E. Castellano. 2001. "Managing and Guiding School Reform: Leadership in Success for All Schools. Educational Administration Quarterly 37: 219-249. doi:10.1177/00131610 121969307.

DuFour, R., and R. J. Marzano. 2011. Leaders of Learning: How District, School, and Classroom Leaders Improve Student Achievement. Bloomington, IN: Solution Tree Press.

Dutton, J. E. 2003. "Breathing Life into Organizational Studies". Journal of Management Studies 12 (1): 5-19.

Eisenhardt, K. M., and M. E. Graebner. 2007. "Theory Building from Cases: Opportunities and Challenges. Academy of Management Journal 50 (1): 25-32. doi:10.5465/AMJ.2007.24160888.

Elmore, R. F. 2004. School Improvement from the Inside Out: Policy, Practice, and Performance. Cambridge, MA: Harvard Education Press. 
Firestone, W. A., and H. D. Corbett. 1988. "Planned Organizational Change.” In Handbook of Research on Educational Administration, edited by N. Boyand, 321-340. White Plains, NY: Longman.

Firestone, W. A., L. Monfils, G. Camilli, R. Y. Schorr, J. E. Hicks, and D. Mayrowetz. 2002. "The Ambiguity of Test Preparation: A Multimethod Analysis in One State." Teachers College Record 104: 1485-1523. doi:10.1111/1467-9620.00211.

Gillborn, D., and D. Youdell. 2000. Rationing Education: Policy, Practice, Reform, and Equity. Buckingham: Open University Press.

Goldring, E., A. Porter, J. Murphy, S. N. Elliott, and X. Cravens. 2009. "Assessing Learningcentered Leadership: Connections to Research, Professional Standards, and Current Practices." Leadership and Policy in Schools 8 (1): 1-36. doi:10.1080/15700760802014951.

Gordon, S. P., and S. R. Brobeck. 2010. "Coaching the Mentor: Facilitating Reflection and Change." Mentoring \& Tutoring: Partnership in Learning 18: 427-447. doi:10.1080/ 13611267.2010.511851.

Hamilton, L., R. Halverson, S. Jackson, E. Mandinach, J. Supovitz, and J. Wayman. 2008. Using Student Achievement Data to Support Instructional Decision Making. Washington, DC: National Center for Education Evaluation and Regional Assistance, Institute of Education Sciences, U.S. Department of Education. Accessed September 20, 2011. http://ies.ed.gov/ncee/wwc/pdf/ practice_guides/dddm_pg_092909.pdf.

Heritage, M. H. 2010. Formative Assessment: Making It Happen in the Classroom. Thousand Oaks, CA: Corwin.

Hess, F., and A. Kelly. 2007. "Learning to Lead: What Gets Taught in Principal Preparation Programs." Teachers College Record 109: 244-274.

Hodges, O. 2014. “A Collection of Documents from the Practicum.” Accessed September 24, 2014. http://hdl.handle.net/10806/12046.

Karanxha, Z., and V. Agosto. 2012. "Curriculum Leadership that Is Culturally Relevent." Paper presented at the 2012 University Council of Educational Administration Convention, Denver, CO, September 11.

Lawrence-Lightfoot, S., and J. H. Davis. 1997. The Art and Science of Portraiture. San Francisco, CA: Jossey-Bass.

Leavitt, B., and J. G. March. 1988. "Organizational Learning”. Annual Review of Sociology 14. doi:10.1146/annurev.so.14.080188.001535.

Leithwood, K., and K. Duke. 1999. "A Century's Quest to Understand School Leadership.” In Handbook of Research on Educational Leadership, edited by J. Murphy and K. S. Louis, 2nd ed., pp. 45-72. San Francisco, CA: Jossey-Bass.

Leithwood, K., D. Jantzi, G. Coffin, and P. Wilson. 1996. "Preparing School Leaders: What Works?" Journal of School Leadership 6: 316-342.

Lincoln, Y. S., and G. E. Guba. 1985. Naturalistic Inquiry. Beverly Hills, CA: Sage.

Louis, K. S., K. Leithwood, S. E. Wahlstrom, and Anderson. 2010. Learning from Leadership: Investigating the Links to Improved Student Learning. Accessed July 18, 2012. http://www. wallacefoundation.org/knowledge-center/school-leadership/key-research/Documents/Investigatingthe-Links-to-Improved-Student-Learning.pdf.

Marsh, J. A. 2012. "Interventions Promoting Educators' Use of Data: Research Insights and Gaps." Teachers College Record 114 (11): 1-48.

Martorell, F., P. Heaton, S. M. Gates, and L. S. Hamilton. 2010. "Preliminary Findings from the New Leaders for New Schools Evaluation. Rand Working Paper Series.” Accessed February 20, 2010. http://www.rand.org/content/dam/rand/pubs/working_papers/2010/RAND_WR739.pdf.

Massell, D. 2000. The District role in Building Capacity: Four Strategies. CPRE Policy Brief. Accessed January 15, 2005. http://www.cpre.org/district-role-building-capacity-four-strategies.

McCarthy, M. 1999. "The Evolution of Educational Leadership Preparation Programs." In Handbook of Research on Educational Administration: A Project of the American Educational Research Association, edited by J. Murphy and K. S. Louis, 119-139. San Francisco: Jossey-Bass.

McLaughlin, M. W., and D. Mitra. 2002. "Theory-based Change and Change Based Theory: Going Deeper, Going Broader." Journal of Educational Change 2: 301-323. doi:10.1023/ A:1014616908334. 
Miles, M. B., A. M. Huberman, and J. Saldaña. 2013. Qualitative Data Analysis: A Methods Sourcebook. 3rd ed. Thousand Oaks, CA: Sage.

Mislevy, R. J., and M. M. Riconscente. 2005. Evidence-centered Assessment Design: Layers, Structures, and Terminology. Principled Assessment Designs for Inquiry Technical Report (9). Accessed September 22, 2011. http://padi.sri.com/downloads/TR9_ECD.pdf.

Murphy, J. 2005. "Unpacking the Foundations of ISLLC Standards and Addressing Concerns in the Academic Community." Educational Administration Quarterly, 41 (1): 154-191. doi:10.1177/ 0013161 X04269580.

Murphy, J., S. N. Elliott, E. Goldring, and A. C. Porter. 2007. "Leadership for Learning: A Research-based Model and Taxonomy of Behaviors." School Leadership \& Management 27 (2): 179-201. doi:10.1080/13632430701237420.

National Policy Board for Educational Administration. 2002. Standards for Advanced Programs in Educational Leadership for Principals, Superintendents, Curriculum Directors, and Supervisors. Accessed June 18, 2012. http://www.ncate.org/LinkClick.aspx?fileticket=jz0BsFs7A80\% 3D\&tabid $=676$.

Neal, D., and D. W. Schanzenbach. 2010. "Left behind by Design: Proficiency Counts and Testbased Accountability." The Review of Economics and Statistics 92: 263-283. doi:10.1016/j. econedurev.2007.06.004.

Nevarez, C., and J. L. Wood. 2007. "Developing Urban School Leaders: Building on Solutions 15 Years After the Los Angeles Riots. Educational Studies 42: 266-280. doi:10.1080/00131940701634676.

O’Day, J. A. 2002. "Complexity, Accountability, and School Improvement." Harvard Educational Review 72: 293-329.

Orr, M. T., and S. Orphanos. 2011. "How Graduate-level Preparation Influences the Effectiveness of School Leaders: A Comparison of the Outcomes of Exemplary and Conventional Leadership Preparation Programs for Principals." Educational Administration Quarterly 47 (1): 18-70. doi:10.1177/0011000010378610.

Orr, M. T., M. D. Young, and A. Rorrer. 2010. Developing Evaluation Evidence: A Formative and Summative Evaluation Planner for Educational Leadership Preparation Programs. Accessed June 1, 2012. http://www.edleaderprep.org.

Paredes Scribner, A. 1999. "Using Student Advocacy Assessment Practices. In Lessons from Highperforming Schools: Creating Learning Communities, edited by P. Reyes, J. D. Scribner, and A. Paredes Scribner, 169-187. New York: Teacher's College Press.

Reback, R. 2008. "Teaching to the Rating: School Accountability and the Distribution of Student Achievement." Journal of Public Economics 92: 1394-1415. doi:10.1016/j.jpubeco.2007.05.003.

Rowan, B., and R. J. Miller. 2007. "Organizational Strategies for Promoting Instructional Change: Implementation Dynamics in Schools Working with Comprehensive School Reform Providers." American Educational Research Journal 44: 252-297. doi:10.3102/0002831207302498.

Saldaña, J. 2003. Longitudinal Qualitative Research: Analyzing Change through Time. Oxford: AltaMira Press.

Skrla, L., K. B. McKenzie, and J. J. Scheurich, 2009. Using Equity Audits to Create Equitable and Excellent Schools. Thousand Oaks, CA: A joint publication with National Association of Secondary School Principals and Corwin.

Spillane, J. P. 2004. Standard Deviations: How Schools Misunderstand Education Policy. Cambridge, MA: Harvard.

Spillane, J. P. 2012. "Data in Practice: Conceptualizing the Data-based Decision-making Phenomena." American Journal of Education 118 (2): 113-141. doi:10.1086/663283.

Spillane, J. P., and D. B. Miele. 2007. "Evidence in Practice: A Framing of the Terrain. In Evidence and Decision Making, edited by P. A. Moss, 46-73. Malden, MA: National Society for the Study of Education.

Stein, M. K., and B. S. Nelson. 2003. "Leadership Content Knowledge." Educational Evaluation and Policy Analysis 25: 423-448. doi:10.3102/01623737025004423.

Supovich, J. 2012. "Getting at Student Understanding-The Key to Teachers' Use of Test Data." Teachers College Record 114 (11): 1-29.

Supovitz, J. A., and V. Klein. 2003. Mapping a course for improved student learning: How innovative schools systematically use student performance data to guide improvement. Accessed June 28, 2005. http://www.cpre.org/mapping-course-improved-student-learning-how-innovative-schools-systematically-use-student-performan. 
Tucker, M. S., and J. B. Codding. 2002. The Principal Challenge: Leading and Managing Schools in An Era of Accountability. San Francisco: Jossey-Bass.

Valenzuela, A. ed. 2004. Leaving Children Behind: How "Texas-style" Accountaility Fails Latino Youth. Albany, NY: SUNY Press.

Webb-Johnson, G. 2006. "To Be Young, Gifted, Emotionally Challenged and Black: A Principal's Role in Providing a Culturally Responsive Context." Voices in Urban Education 12 (Summer): $2-27$.

Wenger, E. 1998. Communities of Practice: Learning, Meaning and Identity. Cambridge: Cambridge University Press. doi:10.1017/CBO9780511803932.

Wiggins, G., and J. McTighe. 2007. Schooling by Design: Mission, Action, and Achievement. Alexandria, VA: ASCD.

Young, M. D., G. J. Peterson, and P. M. Short. 2002. "The Complexity of Substantive Reform: A Call for Interdependence among Key Stakeholders." Education Administration Quarterly 38 (2): $137-175$. 


\section{Appendix}

Table A1. SU internal evaluation data.

\begin{tabular}{|c|c|c|}
\hline Date & Data source & Responsibility \\
\hline 1/2007-Present & $\begin{array}{l}\text { State, NCATE and SACS } \\
\text { accreditation folios and on-going } \\
\text { reporting, including programme } \\
\text { enrolment and demographics }\end{array}$ & $\begin{array}{l}\text { Written by SU programme faculty } \\
\text { and approved dean of COE }\end{array}$ \\
\hline 8/2007-Present & Department meeting notes & First author \\
\hline $\begin{array}{l}\text { 1/2007-Present; } \\
\text { phased in } \\
\text { between } 2007 \\
\text { and } 2009\end{array}$ & $\begin{array}{l}\text { Candidates' digital portfolios } \\
\text { containing annotations and artefacts } \\
\text { from major course assignments } \\
\text { aligned to state leadership standards } \\
\text { and evaluated by faculty. Data from } \\
\text { SU leadership programme field } \\
\text { experiences, including evaluations of } \\
\text { candidates' performance by their } \\
\text { mentors and the university practicum } \\
\text { supervisor. }\end{array}$ & $\begin{array}{l}\text { All USFSP school leadership } \\
\text { development programme faculty }\end{array}$ \\
\hline 8/2007-Present & Collection of syllabi for the practicum & $\begin{array}{l}\text { Content analysis of major course } \\
\text { elements by first author and } \\
\text { SU alum }\end{array}$ \\
\hline $8 / 2007-1 / 2013$ & $\begin{array}{l}\text { Two or more SU leadership } \\
\text { candidate's practicum notebooks from } \\
\text { each semester }\end{array}$ & $\begin{array}{l}\text { Content analysis of major course } \\
\text { elements by first author and } \\
\text { SU alum }\end{array}$ \\
\hline $8 / 2008-8 / 2012$ & $\begin{array}{l}\text { Capstone gallery walk evaluations by } \\
\text { at least } 5 \text { faculty and university } \\
\text { administrators including the dean of } \\
\text { the college of education and the } \\
\text { chancellor or provost of SU } \\
\text { Second author }\end{array}$ & \\
\hline 2010-Present & $\begin{array}{l}\text { Timelines of major events in SU } \\
\text { leadership programme }\end{array}$ & First author \\
\hline 2012-Present & $\begin{array}{l}\text { Curriculum mapping and evaluation } \\
\text { to align SU to revised state leadership } \\
\text { preparation standards; all course } \\
\text { assignments and rubrics in the SU } \\
\text { leadership programme }\end{array}$ & $\begin{array}{l}\text { Joint work of first and second } \\
\text { authors to be approved by the dean } \\
\text { of the college of education }\end{array}$ \\
\hline
\end{tabular}

